\title{
ETHICAL ASPECTS OF COMMUNICATION IN THE ACADEMIC ENVIRONMENT
}

The changes in the academic environment are related to the changes in the organisational culture and subsequently also in communication at universities. Transformation of universities from temples of knowledge into organisations producing qualified workforce and research findings applicable in practice is very important in this process. Changes in the relations and communication among academic staff as well as between the management of universities and their employees are connected with this process too. The presented paper focuses on these relations and communication among academics and between academics and the management of universities in detail. The method of secondary analysis of data collected by means of an organizational climate questionnaire at a teacher training faculty was applied in the article. The analysis of the mentioned data illustrates perception of the management's communication by the academic staff.

Keywords: Ethic, communication, university, academics, organisational climate, management.

\section{Introduction}

Ethical issues of professional communication and communication in an organisation have recently been the subject of many studies [1-4]. The revived interest is related to changes of professions and organisations where communication is carried on. What has been changing in recent times is organisations' visions and missions, their organisational structure as well as requirements for employees. This is why it is necessary to pay more attention to communication that has been changing due to information technologies too. Communication among organisations' managements, middle management and employees is more and more frequently not carried out face-to-face but using technical communication means. ${ }^{1}$ The impact of these changes can be observed also on the level of universities as organisations affected by organisational and technological changes. Universities stop being temples of knowledge but are approached as producers of knowledge and qualified workforce. The change of the substance of universities causes an increase of interest in research of communication climate too [5-8].

It is typical of universities to describe their organisation as collegial $[9$, p. $15 ; 10$, pp. 4-5], based on participative decision

${ }^{1}$ In this context, a warning by Norbert Wiener [11, pp. 79-80] has already been mentioned in relation to phonetic and semantic changes of speech and thus its comprehensibility.

\footnotetext{
* 1,2Helena Grecmanova, ${ }^{2}$ Miroslav Dopita, ${ }^{1,3}$ Eva Urbanovska

${ }^{1}$ Faculty of Humanities, University of Zilina, Slovakia

${ }^{2}$ Faculty of Arts, Palacky University Olomouc, Czech Republic

${ }^{3}$ Faculty of Public Policy, Silesian University in Opava, Czech Republic
}

E-mail: helena.grecmanova@fhv.uniza.sk making. Actions are based on consensus and discussion. Power is represented by experts and professionals. The structure of the collegial organisational frame is circular. Metaphorically, it can be described as a circle. The legal process, the faculty senate and professional associations are typical examples of this organisational framework. Leadership corresponds with the rule "first among equals". Communication is protracted and oral based. The scope of influence is faculty. The reward structure is based on expertise in discipline and peer review. Academic disciplines are the source of structure. Co-workers perceive workers as colleagues.

Communication with co-workers as colleagues emphasises establishment and observance of communication rules that are reflected directly in the ethics of communication. "Communication ethics are central to the dialogic process of negotiating contending social goods in a postmodern society, an era of narrative and virtue contention" [1, pp. 143-144]. Janie M. H. Fritz [3, p. 57] states that "Communication in the workplace is an ethical matter because it has consequences for the task and relationship areas of organizational life. Principles of communication ethics in the workplace are applicable at the individual, dyadic and team level. Applying communication ethics in the workplace setting requires thoughtful discernment of the consequences of communication for the organization and the people who work in it." 
Charles W. Redding [12], classic of studies of communication in organisation, specified five factors in relation to communication climate as one of the variants of organisational climate; these are: supportiveness; participative decision making, trust, confidence, credibility; openness and candour; and high performance goals. Marshall Poole [13, p. 107] added some reflections about ideal communication climate containing five dimensions: "collective beliefs, expectations, and values regarding communication, and is generated in interaction around organizational practices via a continuous process of structuration". Communication climate is created by continuous evaluation of interactions with other members of the organisation. Still, statistical analyses of communication climate researches have shown also other dimensions. Pamela Shockley-Zalabak [14, pp. 356-358] describes dimensions of structure, decision making, motivation, creativity and teamwork.

A process of creating positive communication climate was suggested in an already classical study by Jack Gibb [15]. He defined characteristics of communication leading to supportive communication climate on the one hand, and characteristics triggering off defensive mechanisms in an individual on the other hand. These make communication harder or even impossible, creating defensive communication climate. He defines defensive behaviour as behaviour that is carried out when an individual perceives or presumes a threat of attack in the group. A person acting defensively dedicates a great deal of energy to their selfdefence, is not able to perceive precisely motives, values and emotions in their communication partners (message transmitters). Their own anxieties, motives and worries are mixed in the content of the received message. The person takes a defensive position, and thus arouses these tendencies in other persons too, and the subsequent circle response becomes destructive. Efficiency of communication decreases. This is confirmed also by Richard Bessoth [16] who accentuates trust between an organisation's management and employees; if trust is lacking between them a great deal of energy and time is dedicated to measures for their own defence. Information is not passed on, nobody takes risk.

What can be used for research on communication on the level of universities is, among other approaches, research of organisational climate using a questionnaire. Our study is based on a secondary analysis of research data the objective of which was designing a research tool (questionnaire) for measuring organisational climate of academic workplaces [17]. The opportunity to evaluate the field of communication at particular faculties turned out to be an added value.

\section{Objectives and hypotheses}

The objective of the secondary data analysis is to analyse selected aspects of communication of department managements and faculty managements. Two hypotheses were formulated in relation to studied communication of department and faculty managements:

H1: Evaluation of sufficient feedback from department managements is significantly related to evaluation of quality of criticism reasoning from department managements.

$\mathrm{H} 2$ : Evaluation of communication between faculty managements and employees and workplaces is significantly related to the studied partial indicators of good communication from faculty managements.

\section{Method}

The designed organisational climate questionnaire was tested in a pilot study, and it contained 70 items at the stage of partial study on which we based our paper. The questionnaire design followed the structure of items describing behaviour of academic staff as well as behaviour of department managements and, last but not least, behaviour of faculty managements. Each of the mentioned areas contained questions explicitly focused on communication of a result of communication. Ten items evaluating communication of department managements ( 3 items) and faculty managements ( 7 items) were chosen for secondary analysis. Respondents were academic staff answering the questions by means of a 5-point scale: I definitely agree (1), I rather agree (2), I cannot say (3), I rather disagree (4), and I definitely disagree (5). Questionnaire returnability was 60\% (117 questionnaires). Cronbach's alpha coefficient was 0.94 in this version of the questionnaire as a whole [17, p. 77].

\section{Results}

The data analysis is based on medians and quartiles. The mentioned statistical parameters are presented graphically. Lower scale values mean more positive climate in the particular dimension. The scale is inverted and marked with letter $\mathrm{R}$ in negatively formulated items, as shown in tables and figures of department and faculty managements' behaviour. Correlations in all the below mentioned questionnaire items focused on communication are indicated by means of Spearman's correlation coefficient for ordinary data on significance level 0.01 .

Communication analysis in the field of behaviour of department managements showed statistical significance in all the three correlated items (Table 1). Medium statistical dependence was indicated between the item of sufficient feedback from department managements to staff (item 38) and good reasoning of criticism of academics' work from the corresponding workplace (item 39). In other words: the more comprehensible reasoning of criticism from the particular workplace, the more positive evaluation of sufficient feedback on the quality of their work from the staff (and vice versa). 
Spearman's correlations of communication in the field of the department managements' behaviour.

The marked correlations are significant on the level $p<.01000$.

Table 1

\begin{tabular}{|c|c|c|c|}
\hline \multirow[t]{2}{*}{ Items (item numbers and wordings) } & \multicolumn{3}{|c|}{$\begin{array}{l}\text { Department managements' } \\
\text { behaviour (item numbers) }\end{array}$} \\
\hline & 34 & 38 & 39 \\
\hline $\begin{array}{l}34 \text { Tasks assigned by the workplace management (department, institute management) are comprehensible } \\
\text { for the academic staff. }\end{array}$ & $\mathrm{x}$ & 0.343586 & 0.372391 \\
\hline $\begin{array}{l}38 \text { The academic staff receive sufficient feedback on the quality of their work from the workplace } \\
\text { management (department, institute management). }\end{array}$ & & $\mathrm{X}$ & 0.568470 \\
\hline $\begin{array}{l}39 \text { If the workplace management (department, institute management) criticises the academic staff work, the } \\
\text { opinions are well reasoned. }\end{array}$ & & & $\mathrm{x}$ \\
\hline
\end{tabular}

A negative result was found in the item focused on feedback of the quality of staff' work in interpretation of items studying communication with department management (item 38), as proved by Fig. 1 .

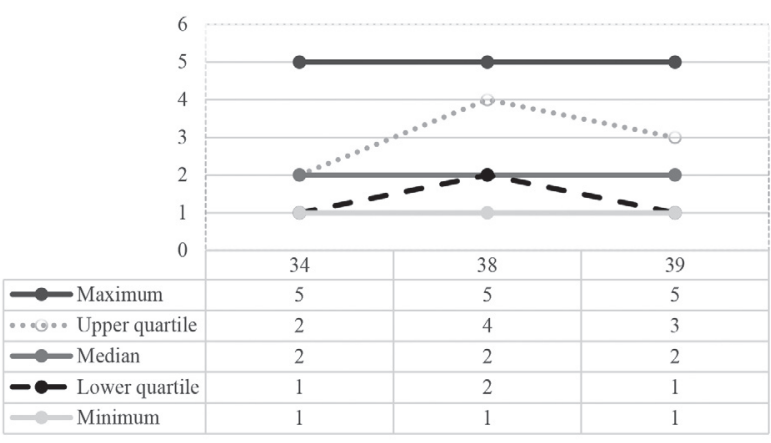

Fig. 1 Department managements' behaviour ( $n=117)$

Based on the above findings, it is possible to accept hypothesis H1.

Spearman's correlations of communication in the field of the faculty management's behaviour.

The marked correlations are significant on the level $\mathrm{p}<.01000$. The correlation in italics is significant on the level $\mathrm{p}<.05$.

Table 2

\begin{tabular}{|c|c|c|c|c|c|c|c|}
\hline \multirow{2}{*}{$\begin{array}{l}\text { Items } \\
\text { (item numbers and wordings) }\end{array}$} & \multicolumn{7}{|c|}{ Faculty management's behaviour (item numbers) } \\
\hline & 43 & 46 & 47 & 48 & 54 & 61 & 66 \\
\hline $\begin{array}{l}43 \text { Criteria of evaluation of the academic staff's work are } \\
\text { clearly articulated. }\end{array}$ & $\mathrm{x}$ & -0.478699 & -0.534886 & 0.358757 & 0.257812 & 0.525386 & 0.527163 \\
\hline 46 The faculty management does not admit its failures. & & $\mathrm{x}$ & 0.633791 & -0.454158 & -0.305480 & -0.533605 & -0.626062 \\
\hline $\begin{array}{l}47 \text { The faculty management makes decisions mostly } \\
\text { "behind closed doors". }\end{array}$ & & & $\mathrm{x}$ & -0.530142 & -0.193635 & -0.442610 & -0.559634 \\
\hline $\begin{array}{l}48 \text { I can comment on important decisions of the faculty } \\
\text { management. }\end{array}$ & & & & $\mathrm{X}$ & 0.171734 & 0.285545 & 0.447819 \\
\hline 54 Faculty events are announced in time. & & & & & $\mathrm{x}$ & 0.357113 & 0.321258 \\
\hline $\begin{array}{l}61 \text { Communication between the faculty management and } \\
\text { my workplace (department, institute) is efficient. }\end{array}$ & & & & & & $\mathrm{X}$ & 0.571879 \\
\hline $\begin{array}{l}66 \text { The faculty management reasons conceptual changes } \\
\text { properly. }\end{array}$ & & & & & & & $\mathrm{X}$ \\
\hline
\end{tabular}

Statistically significant correlations were found in nearly all the observed characteristics of faculty managements' communication (Table 2). Besides others, a correlation was indicated in evaluation of efficiency of communication between faculty managements and particular workplaces and all the other studied items. This also confirms validity of the formulated hypothesis H2. The only item where correlation was not identified is possibility to express one's opinion about the faculty's important decisions (item 48) in relation to early announcement of faculty affairs (item 54). Contrary to the other confirmed correlations, it shows low dependence in relation to other items. Another exception is the correlation of the item focused on prevailing faculty managements' decision-making "behind closed doors" (item 47) with early announcement of faculty affairs (item 54) that was proved significant on level $\mathrm{p}<.05$.

When analysing ways of communication by faculty managements, the respondents state that criteria of evaluation of academic staff work are frequently not clearly formulated (item 43 ), that evaluators do frequently not have an opportunity to comment on important decisions of faculty managements (item 48 ), and that faculty managements frequently make decisions 
"behind closed doors" (item 47R); values of median and quartiles based on the reverted scale of negatively formulated items correspond with this (Fig. 2).

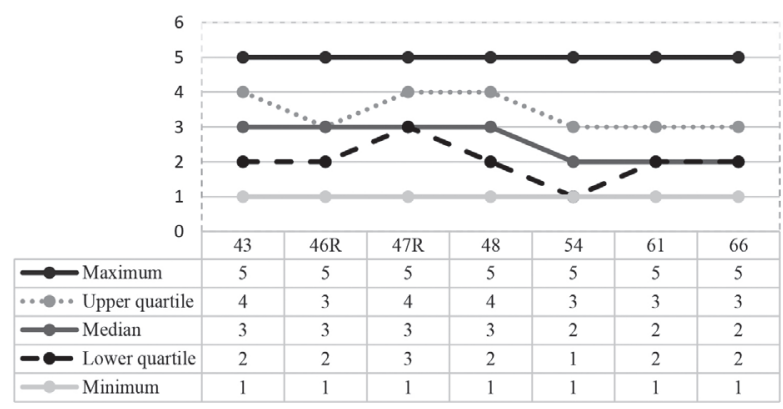

Fig. 2 Faculty management's behaviour ( $n=117)$

\section{Discussion}

The analysed values and correlations of department managements' communication indicate relative satisfaction with communication, except for evaluation of the item focused on receiving feedback about the quality of academic staff work. The confirmed correlation between providing feedback and reasoning criticism can be an evidence of interconnection of these two communication competencies on the one hand. It means that if a workplace's head does not provide sufficient feedback then she/he does not reason their criticism. The identified link could also be explained by the fact that the greater problems a superior has with reasoning criticism, the less willing she/he is to provide feedback about the quality of their subordinates' work, and vice versa. Still, this statement is rather hypothetical, it is necessary to verify its validity. On the other hand, it is necessary to consider the evaluator's personality and the human tendency to maintain consistency of one's attitudes as the cause of this phenomenon. In this context, the more negatively an evaluator evaluates the quality of reasoning of criticism from their superiors, the more negatively she/he can evaluate provision of feedback. In any case, both the competencies rank among the fundamental assertive skills and should be developed sufficiently in all managers. It can be said that our finding corresponds with the knowledge published in literature [see e.g. 18] on the importance of providing feedback and constructive criticism while accepting all ethical principles. Jiri Mares and Jaro Krivohlavy [19, p. 96] deal with feedback and, as we can say, criticism as a cognitive correcting and regulating information on a person interested in a process in which they participate and care about. Further, the importance of feedback for employees is on the developmental and social levels; thus, its lack in an organisation is significant. According to Joseph Basile [20, p. 45], an employee who is seriously informed of their performance and whom his/her superior really consults is selfconscious and tries to be effective. If she/he is allowed to think, express herself/himself, accept responsibility, she/he grows.
Frequency of the confirmed correlations in the area of communication between academic staff and faculty managements indicates interconnection of particular communication skills. If there are weaknesses or, on the contrary, strengths identified in one dimension, they usually show in other dimensions too. The results also indicate dependence of more global evaluation of communication efficiency on partial indicators. It means that if an individual evaluates the faculty management's communication with her/his own workplace as efficient or inefficient it is supported by not one but several characteristics of behaviour or several manifested competencies.

The secondary analysis of the items focused on evaluation of faculty managements' communication indicates necessity of paying more attention to faculty managements' communication with academic staff. It can be stated at the cost of slight simplification that friendliness in communication is disappearing on the higher levels of the management hierarchy at the studied faculty. What can also be considered is superiority complex characterised by Alfred Adler [21, p. 63] as clearly showing in attitudes, in exaggerated opinion about oneself, one's talent and abilities, in exaggerated requirements for oneself and others. The overall view of the results of the performed data analysis is in correspondence with the described theoretical starting points and the mentioned factor models supporting positive communication climate and healthy communication.

\section{Conclusion}

We succeeded in analysing significant characteristics of academic communication based on the secondary analysis of data from an organisational climate research. With regard to the study objective, evaluation of department and faculty managements' communication with academic staff was chosen where the communication processes between academic staff and faculty managements are experienced in a more negative way in comparison with evaluation of communication on the level of department managements.

In relation to the found facts, it is necessary to approach the academic environment as an organisation where rules of communication and communications ethics apply. "Practicing communications ethics contributes to climate of integrity in the workplace, fostering and ensuring both personal and institutional flourishing" [3, p. 44]. The starting point is showing mutual respect and common decency. Interpersonal communication can help society experiencing the crisis of values [22, p. 129], and only a cultivated person can keep control over a situation. According to Ladislav Lencz [23], ethical behaviour in a human is shown in respect for oneself as well as the others, ability of empathy, ability of considering needs and interests of both an individual and society by exceeding the limits of one's own "I". 


\section{Acknowledgements}

Some results presented in this article were supported by the Czech Science Foundation (project no. P407/11/0696 Perception of Organizational Climate of Faculties of Education by Academic Staff) and the Faculty of Arts, Palacký University Olomouc (IGA FF 2015035 Integrated Social Science Research).

\section{References}

[1] ARNETT, R. C., ARNESON, P., BELL, L. M.: Communication Ethic: The Dialogic Turn. In ARNESON, P. (ed.): Exploring Communication Ethics: Interviews with Influential Scholars in the Field. New York: Peter Lang, 2007, pp. 143-184. ISBN 978-0-82048824-0.

[2] BLYLER, N. R., THRALlS, C. (eds.).: Professional Communication: The Social Perspective. London: Sage, 1993, 296 pp. ISBN 978-0-8039-3935-3.

[3] FRITZ, J. M. H.: Ethics Matters: Why Ethical Communication Makes a Difference in Today's Workplace. In WRENCH, J. S. (ed.): Workplace Communication for the 215t Century: Internal Workplace Communication. Santa Barbara: Praeger, 2013, pp. 39-60. EISBN 978-0-313-39632-8.

[4] WRENCH, J. S. (ed.): Workplace Communication for the 21st Century: Internal Workplace Communication. Santa Barbara: Praeger, 2013, 772 pp. EISBN 978-0-313-39632-8.

[5] PETERSON, M. W.: The Study of Colleges and Universities as Organization. In GUMPORT, P. J. (ed.): Sociology of Higher Education. Contributions and Their Context. Baltimore: The Johns Hopkins University Press, 2007, pp. 147-184. ISBN 978-0-80188615-7.

[6] LOUIS, K. S., HOLDSWORTH, J. M., ANDERSON, M. S., CAMPBELL, E. G.: Becoming a Scientist: The Effects of Work-Group Size and Organizational Climate. The J. of Higher Education, 2007, 78, 3, pp. 311-336. ISSN 0022-1546.

[7] MCMURRAY, A., SCOTT, D.: Determinants of Organisational Climate for Academia, Higher Education Research and Development. 2013, 32, 6, pp. 960-974. ISSN 0729-4360.

[8] MUSAH, M. B., ALI, H. M., VAZHATHODI AL-HUDAWI, S. H., TAHIR, L. M., DAUD, K. B., SAID, H. B., KAMIL, N. M.: Organisational Climate as a Predictor of Workforce Performance in the Malaysian Higher Education Institutions. Quality Assurance in Education: An International Perspective, 2016, 24, 3, 416-438. ISSN 0968-4883. doi:10.1108/QAE-10-2014-0048

[9] CHAFFEE, E. E.: Rational Decision Making in Higher Education. Boulder: National Center for Higher Education Management Systems, 1983, 92 pp.

[10] MANNING, K.: Organizational Theory in Higher Education. New York: Routledge, 2013, 232 pp. ISBN 978-0-415-87467-0.

[11] WEINER, N.: The Human Use of Human Beings. Cybernetics and Society. London: Free Association Books, 1989 [1950], 208 pp. ISBN 1-85343-075-7.

[12] REDDING, W. C.: Communication within the Organization. New York: Industrial Communication Council, 1972.

[13] POOLE, M.: Communication and Organizational Climates. Review, Critique, and a New Perspective. In MCPHEE, R. D., TOMPKINS, P. K. (eds.): Organizational Communication: Traditional Themes and New Directions. Beverly Hills: Sage, 1985, pp. 79-108. ISBN 978-0-8039-2187-0.

[14] SHOCKLEY-ZALABAK, P.: Fundamentals of Organizational Communication. Knowledge, Sensitivity, Skills, Values. New York: Longman, 1988. ISBN 0-582-28635-2.

[15] GIBB, J. R.: Defensive Communication. J. of Communication, 1961, 11, 3, pp. 141-148. ISSN 1460-2466.

[16] BESSOTH, R.: K.L.I.M.A.: Five Strategies of Leadership that Bring Everyone on Board. Development of New Management Concepts (in German). Pädagogische Führung, 2003, 14, 3, pp. 122-128. ISSN 0939-0413.

[17] GRECMANOVA, H., DOPITA, M. et al: Organizational Climate of Teacher Training Faculties (in Czech). Olomouc: Univerzita Palackého v Olomouci, 2013, 166 pp. ISBN 978-80-244-3863-4.

[18] VYBIRAL, Z.: Psychology of Communication (in Czech). Praha: Portal, 2009, 319 pp. ISBN 978-80-7367-387-1.

[19] MARES, J., KRIVOHLAVY, J.: Communication in School (in Czech). Brno: Masarykova univerzita, 1995, 210 pp. ISBN 80-2101070-3.

[20] BASILE, J.: Cultural Development of Managers, Executives, and Professionals (in Czech). Praha: Svoboda, 1970, 104 pp.

[21] ADLER, A.: The Meaning of Life (in Slovak). Bratislava: IRIS, 1998, 169 pp. ISBN 80-88778-05-0.

[22] ROCHE OLIVAR, R.: Psychology and Education for Pro-Sociality: Optimization of Attitudes and Behaviours of Generosity, Help, Cooperation and Solidarity: A Program Appropriate to School and Family Contexts (in Spanish). Barcelona: Universitat Autonoma de Barcelona, 2002, 291 pp. ISBN 84-490-0327-X.

[23] LENCZ, L.: The Slovak Ethical Education Project. Cambridge Journal of Education, 1994, 24, 3, pp. 443-451. ISSN 0305-764X. 